\title{
Magdalena MiśKowieC
}

Uniwersytet Jagielloński; Instytut Rozwoju Miast, Kraków, Polska • Jagiellonian University; Institute of Urban Development, Cracow, Poland

\section{Przemiany terenów poprzemystowych w miejscach dziedzictwa przemysłu włókienniczego na przykładzie Manchesteru, Lyonu i Łodzi}

\section{The Transformations of Postindustrial Areas in Places of the Textile Industry Heritage, Examples of Manchester, Lyon and Lodz}

\begin{abstract}
Streszczenie: $\mathrm{W}$ wyniku istotnych przemian technologicznych w XX wieku w znacznej części uprzemysłowionych miast europejskich doszło do stopniowej relokacji i zaniku przemysłu. Skutecznym narzędziem przestrzenno-funkcjonalnych przekształceń zdegradowanych terenów jest rewitalizacja. Niniejszy artykuł stanowi próbę oceny przekształceń struktury przemysłowej i zurbanizowanej w tkance miejskiej ośrodków historycznie związanych z przemysłem włókienniczym. Zestawienie porównawcze dotyczyć będzie największych ośrodków dziedzictwa przemysłu włókienniczego w Wielkiej Brytanii, Francji oraz w Polsce. Głównym celem artykułu jest identyfikacja układu przestrzennego pofabrycznych obiektów przemysłu włókienniczego w skali miasta oraz charakterystyka procesów przemiany. Zaprezentowano przykłady zaadaptowania obiektów poprzemysłowych do nowych funkcji oraz wykreowania przestrzeni do świadczenia usług turystycznych oraz przestrzeni publicznej dla mieszkańców miasta. Ukazano też rezultaty procesów rewitalizacyjnych oraz potencjał dziedzictwa przemysłu, dający możliwości rozwoju funkcji edukacyjnych, kulturotwórczych, rekreacyjnych oraz turystycznych.
\end{abstract}

\begin{abstract}
As a result of significant technological changes in the 20th century in much of the industrialized European cities there has been a gradual relocation and decline of industry. An effective tool of spatial and functional transformation of degraded areas is revitalization. This article attempts to assess the impact of transformation of industrial and urban structure in city areas historically associated with the textile industry. Comparative analysis is related to the largest centers of the textile industry heritage in the UK, France and Poland. The main aim of the article is to identify the spatial arrangement of the textile industry postindustrial objects in a city scale and to describe transformations. It presents the examples of adapting factory buildings for new purposes and creating space as a destination for tourist services and public space for the residents. It shows the results of revitalization processes and industrial heritage potential that gives opportunities for development of educational, cultural and recreational tourism functions.
\end{abstract}

Słowa kluczowe: Lyon; Łódź; Manchester; przemysł włókienniczy; rewitalizacja; tereny poprzemysłowe

Keywords : Lyon; Łódź; Manchester; postindustrial areas; revitalization; textile industry

Otrzymano: 21 grudnia 2015

Received: 21 December 2015

Zaakceptowano: 11 lipca 2016

Accepted: 11 July 2016 


\section{Sugerowana cytacja / Suggested citation:}

Miśkowiec, M. (2016). Przemiany terenów poprzemysłowych w miejscach dziedzictwa przemysłu włókienniczego na przykładzie Manchesteru, Lyonu i Łodzi. Prace Komisji Geografii Przemysłu Polskiego Towarzystwa Geograficznego, 30(3), 199-212.

\section{WSTĘP}

Przemiany gospodarcze zachodzące w XX wieku doprowadziły do upadku wielu gałęzi przemysłu w miastach europejskich. Stało się to bezpośrednią przyczyną kryzysu ekonomicznego, a ponadto występowania rozległych przestrzennie terenów poprzemysłowych w tkance miasta. Wobec narastającej konkurencji oraz wprowadzania nowych technologii okres transformacji doprowadził do załamania znaczących branż produkcji materialnej, w tym również przemysłu włókienniczego.

Podobne procesy obserwowano na szeroką skalę w trzech przemysłowych ośrodkach miejskich Europy, jakimi są Manchester, Lyon i Łódź. Przy znaczącym udziale procesów rewitalizacyjnych odbudowują one swoją tożsamość w ramach poprzemysłowego dziedzictwa kulturowego. Takie działania umożliwiają odrodzenie zdegradowanych terenów w formie ośrodków świadczących usługi w ramach rozpowszechnionej obecnie turystyki industrialnej. Równocześnie stwarza to szanse na utworzenie nowych przestrzeni publicznych w strukturze miasta, służących przede wszystkim mieszkańcom.

Celem niniejszego artykułu jest identyfikacja przestrzenna obszarów kultury dziedzictwa przemysłu włókienniczego oraz współczesnych procesów zmiany funkcji obiektów pofabrycznych. Zakres obszaru badań w postaci doboru miasta angielskiego, francuskiego i polskiego podyktowany jest kluczowym znaczeniem branży przemysłu włókienniczego $w$ ich historii oraz efektem nadania nowej funkcji terenom poprzemysłowym. We wszystkich wskazanych miastach zakończył się pewien etap w zakresie rewitalizacji wewnątrzmiejskich terenów poprzemysłowych. Artykuł opisuje sztandarowe projekty zrealizowane w miastach, pozwalając na podjęcie analizy dotyczącej konkretnych modeli działań rewitalizacyjnych. Zestawienie porównawcze pozwala na zbadanie skutków konkretnych przekształceń oraz umożliwia ocenę konkretnych działań. Miasta odznaczają się podobnymi uwarunkowaniami demograficznymi - mają porównywalną liczbę mieszkańców. Wcześniejsze doświadczenia Lyonu i Manchesteru w prowadzeniu działań rewitalizacyjnych na terenach poprzemysłowych umożliwiają opracowanie rekomendacji dla najmniej doświadczonego miasta, Łodzi, w przeprowadzaniu podobnych projektów. Równocześnie występują zasadnicze różnice we francuskim i angielskim modelu działań rewitalizacyjnych. Przy analizowaniu studium przypadku wymienionych trzech miast należy brać pod uwagę odmienne uwarunkowania polityczno-gospodarcze występujące w XX wieku. Także szeroko występujące w literaturze badania porównawcze oraz przykłady współpracy wskazanych ośrodków miejskich przyczyniają się do wyboru wskazanego obszaru opracowania. 


\section{CHARAKTERYSTYKA TERENÓW POPRZEMYSŁOWYCH}

Wśród obszarów poddawanych procesom przekształceń w zakresie działań rewitalizacyjnych wyróżnia się m.in. tereny poprzemysłowe, do których zalicza się również tereny pogórnicze, pokolejowe, poportowe i postoczniowe, oraz nieużytkowane tereny magazynowe i składowe. Aby zrozumieć, czym są tereny poprzemysłowe, należy wskazać, że są to obszary, na których nastąpiło przerwanie ciągłości działalności produkcyjnej i związanych z nią bezpośrednio funkcji pomocniczych (takich jak funkcja górnicza, magazynowa, składowa, transportowa) (Domański, 2001).

Poprzez dokonującą się transformację gospodarczą następuje dekapitalizacja i degradacja wielu terenów poprzemysłowych w zabudowie miejskiej. W wyniku tych procesów narastają negatywne zjawiska społeczne - duże bezrobocie, przestępczość oraz ubóstwo (Lorens, Martyniuk-Pęczek, 2009). Jednym z podstawowych narzędzi wykorzystywanych przy procesach naprawczych na terenach poprzemysłowych jest rewitalizacja. Jej głównym celem jest wyprowadzanie ze stanu kryzysowego obszarów zdegradowanych w sposób kompleksowy, poprzez zintegrowane działania na rzecz lokalnej społeczności, przestrzeni i gospodarki. Proces rewitalizacji w kontekście przestrzeni miejskiej ma ponownie ożywić teren po degradacji, podnosząc jakość życia mieszkańców oraz jakość przestrzeni publicznej (Kaczmarek, 2004). W wielu opracowaniach, gdy wymienia się czynniki decydujące o podatności terenów poprzemysłowych na rewitalizację, za kluczowy uznaje się czynnik przestrzenny, czyli położenie terenu w układzie miejskim ze względu na dostępność komunikacyjną oraz sąsiedztwo innych instytucji miejskich (S. Kaczmarek, J. Kaczmarek, 2010). Biorąc pod uw agę długi okres prowadzenia działań rewitalizacyjnych na terenach poprzemysłowych, sam proces można podzielić na cztery podstawowe etapy (Maciejewska, Turek, 2014). Są to:

1. Scharakteryzowanie dotychczasowego sposobu użytkowania terenu.

2. Przygotowanie szczegółowej diagnozy terenu stanowiącej analizę istniejących uwarunkowań oraz lokalnych potencjałów.

3. Rekultywacja terenu, mająca na celu pozbycie się ewentualnych zanieczyszczeń i niekorzystnego ukształtowania.

4. Przypisanie do terenu nowych funkcji gospodarczych, społecznych, ekologicznych i przestrzennych.

W ramach prowadzonych działań rewitalizacyjnych dąży się do osiągnięcia efektu spill-over, nazywanego rewitalizacją otwartą, który wpływa na ożywienie terenów sąsiadujących. Zmiany zachodzące $w$ rewitalizowanym miejscu pozytywnie wpływają na rozwój przyległych obszarów poprzez zmianę funkcji zabudowy, rozwój zdegradowanej infrastruktury, poprawę warunków mieszkaniowych oraz przestrzeni publicznych. Gdy pozytywne efekty przenoszą się tylko na obszar rewitalizacji, bez stymulowania terenów sąsiadujących, mówi się o rewitalizacji zamkniętej. Jako przykład takiej rewitalizacji podaje się fabrykę Izraela Poznańskiego zaadaptowaną na centrum handlowo-rozrywkowo-kulturalne Manufaktura w Łodzi (Świerczewska-Pietras, 2009).

Proces rewitalizacji charakteryzuje się również dwoistym sposobem prowadzenia przemian $\mathrm{w}$ wymiarze morfologicznym. W tym aspekcie wyróżnia się rewitalizację sensu largo, oznaczającą eliminację występujących podstawowych elementów 
morfologicznych oraz wykształcenie całkiem nowych układów urbanistycznych. W efekcie dochodzi do powstania nowych dzielnic, bloków urbanistycznych, których właściwości przestrzenne różnią się od pierwotnych cech morfologicznych przekształconego obszaru - jest to rewitalizacja radykalna sensu largo. Wyróżnia się także rewitalizację sensu largo o charakterze historyzującym, która poprzez nową zabudowę lub podział działek miejskich w jakimś zakresie nawiązuje do pierwotnej zabudowy przemysłowej. Rewitalizacja właściwa, nazywana rewitalizacją sensu stricte, oznacza adaptację istniejącej zabudowy przemysłowej oraz układu przestrzennego do nowych funkcji. W obszarach nieużytkowanych stosuje się uzupełnianie nową zabudową o charakterze industrialnym (Koter, 1994).

\section{STUDIUM PRZYPADKU MANCHESTERU}

Geneza powstania miasta Manchester sięga czasów zakładania osad rzymskich na Wyspach Brytyjskich. W roku 79 n.e. utworzono castrum rzymskie o nazwie Mancunium lub Mamucium w widłach rzeki Irwell i Medlock. Następnie w okresie średniowiecza miasto rozwijało się jako znaczący ośrodek handlowo-rękodzielniczy. Od XVI wieku zyskało pozycję najważniejszego w regionie producenta tkanin oraz ośrodka handlu wełną i lnem. Miało na to wpływ sąsiedztwo dużego dystrybutora wełny, jakim była Irlandia, oraz największego rynku zbytu w Londynie. Korzystne położenie geograficzne w widłach rzek oraz dostęp do surowców energetycznych przyczyniły się do utworzenia w Manchesterze największego ośrodka miejskiego specjalizującego się w przemyśle włókienniczym na świecie. Dynamiczna industrializacja miasta rozpoczęła się w XVII wieku. Dało to początek zakładania rozległych kompleksów przemysłowych, głównie w południowej części miasta oraz punktowo w obrębie centrum. Ze względu na szybki rozwój przemysłu Manchester okrzyknięto „pierwszym na świecie miastem przemysłowym” oraz „przemysłowym klejnotem w koronie brytyjskiej” (Kidd, 1993).

Doskonały system transportu wodnego prowadzonego siecią kanałów oraz pierwsza oddana do użytku pasażerska linia kolejowa na świecie sprzyjały rozwojowi handlu. Konsekwentnie w strukturze przestrzennej wzdłuż sieci kanałów rzecznych lokalizowano zwartą zabudowę magazynowo-składową. Świetna pozycja czołowego ośrodka przemysłu doprowadziła do dynamicznego wzrostu liczby mieszkańców. Na początku lat trzydziestych XX wieku rozpoczął się kryzys ekonomiczny i społeczny, prowadzący do stopniowego upadku przemysłu włókienniczego w Manchesterze. Konsekwencją eliminacji przemysłu była degradacja terenów przemysłowych, które wymagały przekształceń przestrzennych i funkcjonalnych.

Władze miasta podjęły pierwsze działania naprawcze w latach osiemdziesiątych XX wieku. Najważniejsze działania rewitalizacyjne przeprowadzono w dzielnicy Castlefield, w której zachowało się najwięcej historycznej zabudowy przemysłowej Manchesteru. Z tego względu 1,8 ha powierzchni dzielnicy objęto ochroną pierwszego w Wielkiej Brytanii Parku Dziedzictwa Miejskiego (Urban Heritage Park) (Gibson, 1997). Podstawowym celem utworzenia parku było prowadzenie kompleksowych działań, aby zachować istniejącą zabudowę poprzemysłową oraz poddać ją renowacji i adaptacji do nowych funkcji. Równocześnie wykorzystano potencjał układu kanałów wodnych 
Ryc. 1. Najważniejsze inwestycje zagospodarowania obiektów pofabrycznych w procesie rewitalizacji w dzielnicy Castlefield, Manchester

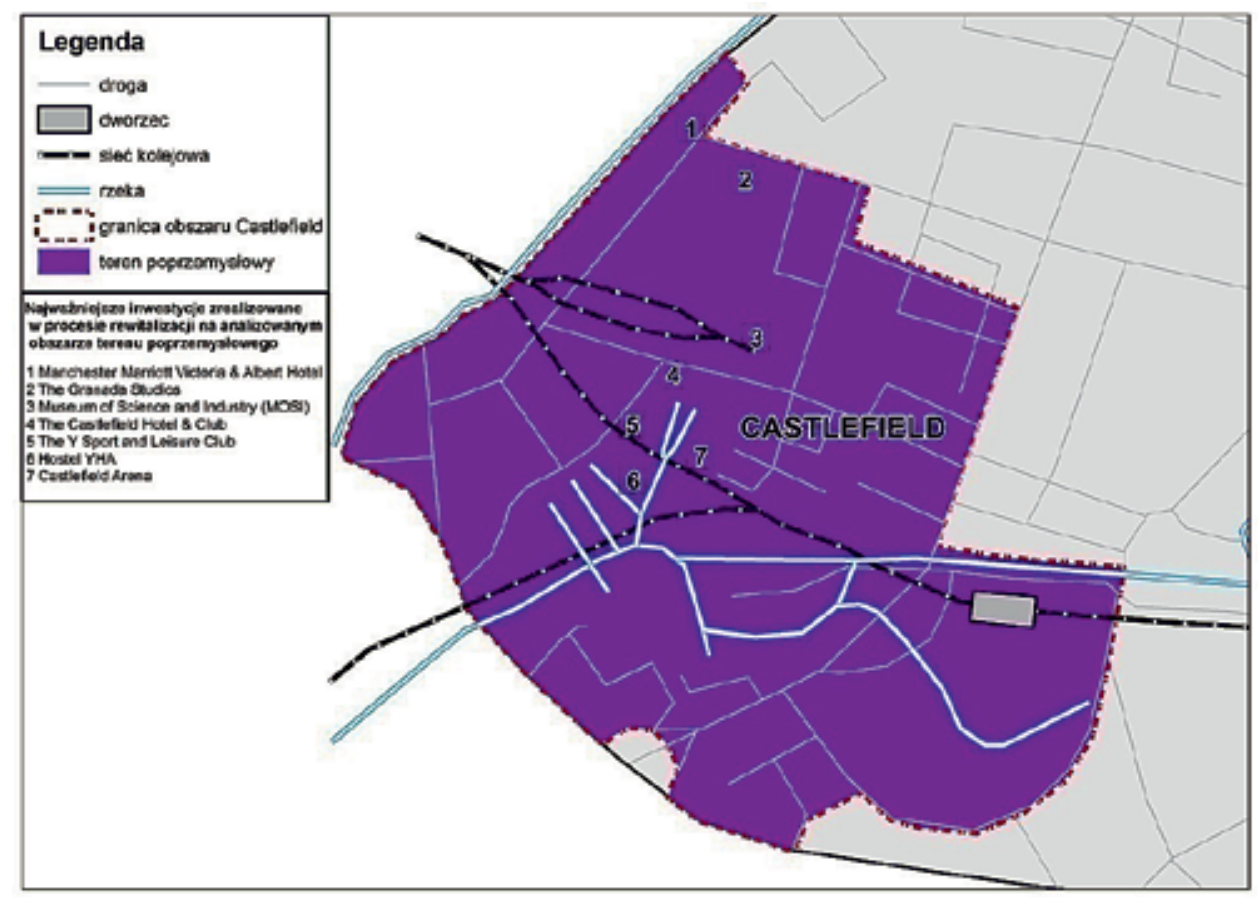

Źródło: opracowanie własne na podstawie Kazimierczak (2012)

Tab. 1. Przekształcenia sposobu użytkowania terenów poprzemysłowych $\mathrm{w}$ Manchesterze $\mathrm{w}$ latach 1988-2013

\begin{tabular}{|l|c|c|}
\hline \multicolumn{1}{|c|}{ Cecha (jednostka) } & Stan w roku 1988 & Stan w roku 2013 \\
\hline Powierzchnia zabudowy (ha) & 22,5 & 28,8 \\
\hline $\begin{array}{l}\text { Powierzchnia nowej zabudowy wzniesionej } \\
\text { w ramach rewitalizacji (ha) }\end{array}$ & 0 & 12,9 \\
\hline $\begin{array}{l}\text { Powierzchnia zachowanej zabudowy } \\
\text { poprzemysłowej zaadaptowanej do nowych } \\
\text { funkcj w ramach rewitalizacji (ha) }\end{array}$ & 0 & 6,9 \\
\hline Powierzchnia zabudowy usługowej (ha) & 2,8 & 16,1 \\
\hline $\begin{array}{l}\text { Powierzchnia zabudowy mieszkaniowej } \\
\text { (ha) }\end{array}$ & 4,0 & 1,7 \\
\hline $\begin{array}{l}\text { Powierzchnia nieużytków } \\
\text { poprzemysłowych (ha) }\end{array}$ & 15,7 & 0,45 \\
\hline $\begin{array}{l}\text { Powierzchnia zachowanej zabudowy } \\
\text { poprzemysłowej w dzielnicy } \\
\text { Castlefield (ha) }\end{array}$ & 0,81 & 0,33 \\
\hline $\begin{array}{l}\text { Powierzchnia zaadaptowanej zabudowy } \\
\text { poprzemysłowej do nowych funkcji } \\
\text { w dzielnicy Castlefield (ha) }\end{array}$ & 0 & \\
\hline
\end{tabular}

Źródło: opracowanie własne na podstawie Kazimierczak (2014) 
i ciągów pieszych, tworząc waterfronty z przeznaczeniem na cele rekreacyjne i turystyczne. Obecnie dzielnica Castlefield po rewitalizacji została przystosowana przede wszystkim do celów rekreacyjnych oraz do świadczenia usług turystyki industrialnej.

Jednym z największych przedsięwzięć rewitalizacyjnych jest przekształcenie pierwszej na świecie kolejowej stacji pasażerskiej Liverpool Road na Muzeum Nauki i Przemysłu (Museum of Science and Industry). Muzeum posiada kolekcję obiektów dziedzictwa przemysłu włókienniczego i kolejowego, doskonale obrazującą historię rewolucji przemysłowej w Manchesterze. Innym przykładem adaptacji obiektu poprzemysłowego jest utworzenie siedziby studia telewizyjnego The Granada Studios na Quay Street. Do 2013 roku była ona najdłużej działającą niezależną stacją telewizyjną w Wielkiej Brytanii. Obecnie można zwiedzać studio telewizyjne, odbywają się tam również wystawy i wydarzenia artystyczne (Milestone, 2016).

$\mathrm{W}$ postindustrialnej przestrzeni dzielnicy Castlefield zdecydowanie najwięcej jest przypadków jej zagospodarowania na cele turystyczne, hotelowe i rekreacyjno-wypoczynkowe (Castlefield Arena, Manchester Marriott Victoria and Albert Hotel, The Castlefield Hotel \& Club, The Y Sport and Leisure Club, Hostel YHA). W odpowiedzi na wzrost zainteresowania turystów dziedzictwem przemysłowym $w$ dzielnicy w historycznych budynkach pofabrycznych stworzono bazę turystyczną. Wykorzystano również doskonale wpisany w teren układ kanałów rzecznych, przede wszystkim Bridgewater i Rochdale, jako przestrzeń publiczną o walorach rekreacyjnych (Kazimierczak, 2012). Rewitalizacja tego rejonu przewidywała przede wszystkim zachowanie istniejącego układu urbanistycznego zabudowy poprzemysłowej i zaadaptowanie go na miejsce spacerów, do świadczenia usług wypoczynkowych i innych uzupełniających profil turystyczny.

Wśród analizowanych obszarów poprzemysłowych w Manchesterze w dzielnicy Castlefield zachowano 25\% ogólnej powierzchni historycznej zabudowy w 2013 roku w porównaniu do 45\% powierzchni w 1988 roku jeszcze przed rewitalizacją. Ponadto stopień wykorzystania zachowanej zabudowy poprzemysłowej do nowych funkcji wynosił 74\% zachowanej powierzchni. Charakter działań rewitalizacyjnych w Castlefield można określić jako rewitalizację właściwą sensu stricte, wykorzystującą potencjał zabudowy industrialnej oraz układu przestrzennego i prowadzącą do adaptacji do pełnienia nowych funkcji. Obecnie występuje tam najmniej poddany przekształceniom krajobraz industrialny, przywołujący dawny charakter miasta Manchester.

\section{STUDIUM PRZYPADKU LYONU}

Miasto Lyon, podobnie jak Manchester, zostało założone jako osada rzymska Lugdunum w 43 roku p.n.e. Od początku osada rozwijała się na wzgórzu Fourvière, a po upadku Cesarstwa Rzymskiego - na półwyspie między rzekami Saoną i Rodanem. Lyon dużo wcześniej zaczął rozwijać się jako miasto przemysłowe, ponieważ już w XIII wieku powstawały tu pierwsze manufaktury włókiennicze. Lyon określano mianem „światowej stolicy jedwabiu" i najważniejszego ośrodka w historii rewolucji przemysłowej we Francji. Pomimo dominacji przemysłu włókienniczego w okresie industrializacji Lyonu nie miało to znaczącego wpływu na strukturę społeczną miasta (Straszewicz, 1987). 
W XVIII wieku w południowej części Lyonu wyznaczono największą dzielnicę przemysłową - Confluence, o powierzchni 150 ha. Wobec dogodnego położenia w widłach rzek Saony i Rodanu oraz dobrze rozwiniętej infrastruktury kolejowej i transportu wodnego dzielnica pełniła funkcję przemysłowo-składowo-komunikacyjną. Oprócz wyjątkowego charakteru zabudowy industrialnej obszar ten traktowano jako odległy, nieprzyjazny, a nawet niebezpieczny. Było to efektem wybudowania w północnej części dworca kolejowego Perrache oraz, od strony wschodniej, śródmiejskiej autostrady, które odizolowały dzielnicę od reszty miasta (Coudroy de Lille, 2003). W XX wieku Lyon także przeżywał kryzys ekonomiczny, skutkiem czego był spadek zatrudnienia w przemyśle na rzecz sektora usług.

Wdrażając procesy rewitalizacji na terenie Confluence, przewidywano przede wszystkim przywrócenie dostępności obszaru pofabrycznego oraz wprowadzenie nowej funkcji usługowo-biznesowej. Efektem działań naprawczych były radykalne przekształcenia przestrzenno-funkcjonalne, polegające na zastępowaniu całych kompleksów obiektów poprzemysłowych nową zabudową. Nowe budynki to przede wszystkim apartamentowce, hotele, biura i centra handlowe. W ten sposób dziedzictwo przemysłowe Lyonu w zasadzie nie zostało zachowane, a ważniejszą atrakcją turystyczną jest historyczne centrum miasta wpisane na listę UNESCO.

Jedyne wciąż zachowane nieliczne obiekty pofabryczne w południowo-wschodniej części Confluence oraz w dzielnicy Gerland ulegają degradacji. Obecnie teren jest zagospodarowany i przeznaczonym pod budownictwo mieszkaniowe, przede wszystkim pod nowoczesne apartamentowce (Saône Park, Lyon Islands, Le Monolithe). Na terenach poprzemysłowych powstały obiekty handlowo-gastronomiczne oraz centra rozrywki (Pavillon des Salins, Pavillon des Douanes, Pavillon La Sucrière, Pôle de loisirs). Nowoczesną architekturę zabudowy reprezentuje obiekt galerii sztuki i muzeum - Musée des Confluences. Urbanistyczne otwarcie terenu na inne części miasta uzyskano, wprowadzając kilka przejść dla pieszych w formie kładek rzecznych, tworząc równocześnie atrakcyjne przestrzenie publiczne (Kazimierczak, 2014). Charakterystykę zmian struktury przestrzennej terenów poprzemysłowych w Lyonie można podzielić na poszczególne etapy w przedziałach czasowych (Han, Kim, Choi, 2014):

- regeneracja obszaru po zachodniej stronie torów kolejowych (2001-2005),

- utrzymanie i poprawa infrastruktury drogowej i kolejowej (2005-2007),

- budowa placu Nautique oraz mariny (2007-2008),

- budowa nowej zabudowy wokół placu Nautique (2008-2012),

- budowa obiektów kultury i rekreacji (2012 - obecnie).

Przemiana dzielnicy Confluence przyczyniła się do podniesienia atrakcyjności miasta, wpływając tym samym na wzrost cen nieruchomości. Nowa zabudowa mieszkaniowa składa sie w przeważającej większości z luksusowych apartamentów (stanowiąc $70 \%$ nowych mieszkań). Pozostałe 30\% zabudowy mieszkaniowej tworzą socjalne oraz niedrogie mieszkania, zgodnie z wytycznymi założeń urbanistycznych. Program naprawczy prowadzony w dzielnicy Confluence jest odpowiedzią na chęć promowania Lyonu jako doskonałego miejsca do rozwoju międzynarodowego biznesu. W ten sposób zatracono historyczną tożsamość miejsca jako ważnego ośrodka przemysłowego i wykreowano zupełnie nowy jego wizerunek. Ponadto doprowadzono jedynie do 
Ryc. 2. Najważniejsze inwestycje zagospodarowania obiektów pofabrycznych w procesie rewitalizacji w dzielnicy Confluence, Lyon

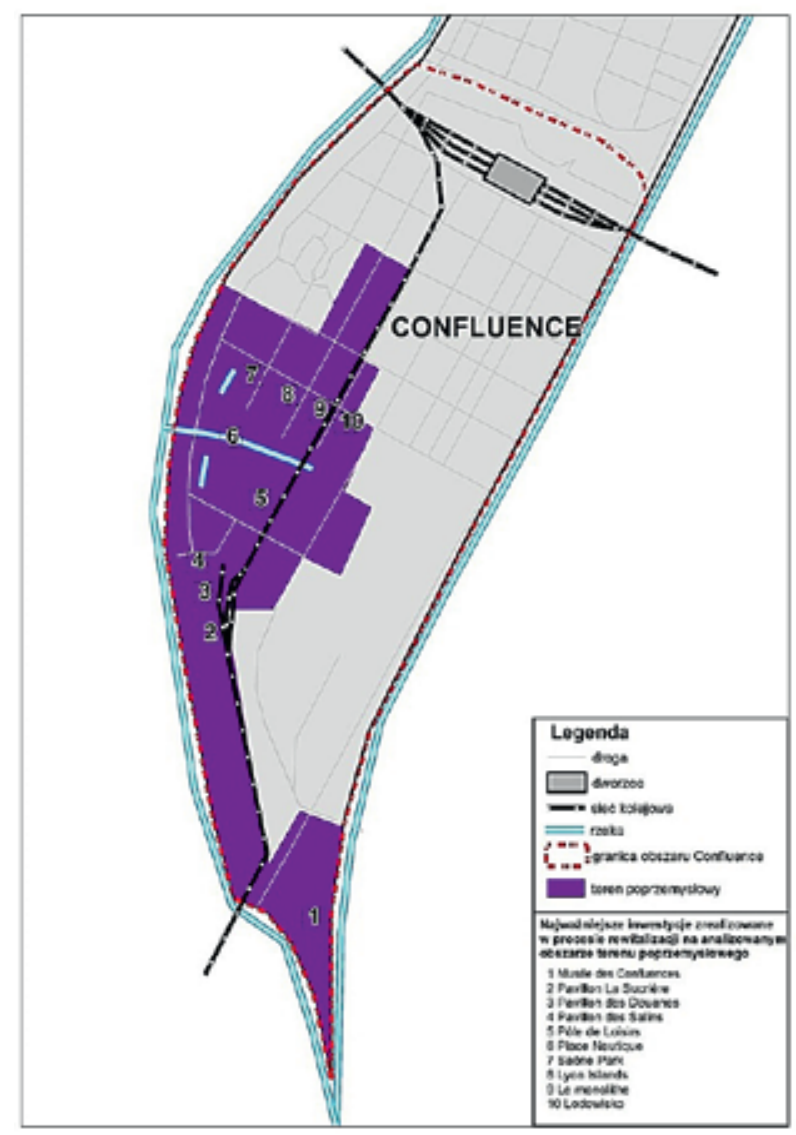

Źródło: opracowanie własne na podstawie Kazimierczak (2012)

Tab. 2. Przekształcenia sposobu użytkowania terenów poprzemysłowych w Lyonie w latach 1988-2013

\begin{tabular}{|l|c|c|}
\hline \multicolumn{1}{|c|}{ Cecha (jednostka) } & Stan w roku 1988 & Stan w roku 2013 \\
\hline Powierzchnia zabudowy (ha) & 14,0 & 12,9 \\
\hline $\begin{array}{l}\text { Powierzchnia nowej zabudowy wzniesionej } \\
\text { w ramach rewitalizacji (ha) }\end{array}$ & 0 & 11,5 \\
\hline $\begin{array}{l}\text { Powierzchnia zachowanej zabudowy } \\
\text { poprzemysłowej (ha) }\end{array}$ & 11,3 & 5,1 \\
\hline Powierzchnia zabudowy usługowej (ha) & 1,5 & 8,3 \\
\hline Powierzchnia zabudowy mieszkaniowej (ha) & 1,2 & 0 \\
\hline Powierzchnia nieużytków poprzemysłowych (ha) & 11,3 & 5,1 \\
\hline $\begin{array}{l}\text { Powierzchnia zaadaptowanej zabudowy } \\
\text { poprzemysłowej do nowych funkcji w dzielnicy } \\
\text { Confluence (ha) }\end{array}$ & 0 & \\
\hline
\end{tabular}

Źródło: opracowanie własne na podstawie Kazimierczak (2014) 
rewitalizacji zamkniętej w granicach dzielnicy Confluence, nie przenosząc jej efektów na obszary sąsiadujące (Carpenter, Verhage, 2014).

W analizowanym obszarze Confluence w Lyonie zauważa się znaczny stopień intensywności przemian dawnej zabudowy przemysłowej. Obszar charakteryzuje się wysokim stopniem przekształcenia dawnego układu przestrzennego oraz funkcji zabudowy. W wyniku prowadzonej radykalnej rewitalizacji sensu largo nie udało się zachować dziedzictwa kulturowego obszaru, wprowadzając jego nowe funkcje i układ przestrzenny.

\section{STUDIUM PRZYPADKU ŁODZI}

Dopóki miasto Łódź w 1423 roku nie uzyskało formalnoprawnej lokacji, było małą miejscowością rolniczą. Nie bez powodu wyznaczenie Łodzi na nowe centrum przemysłu w 1820 roku doprowadziło do rozbudowy licznych obiektów fabrycznych. Pierwsza w Polsce zmechanizowana fabryka w przemyśle włókienniczym uruchomiona została w Łodzi przez Ludwika Geyera w 1839 roku. Sprzyjające położenie geograficzne oraz bliskość ważnych traktów handlowych przyczyniły się do dynamicznego rozwoju Łodzi jako kolebki polskiego przemysłu włókienniczego w XIX wieku. Błyskawiczny rozwój gospodarczy miasta doprowadził do znacznego przyrostu ludności (Liszewski, 1997).

Wobec szybkiego rozwoju przemysłu Łódź uzyskała drugą co do wielkości pozycję ośrodka miejskiego w Polsce oraz stała się przykładem prężnie rozwijającego się miasta przemysłowego Europy Środkowo-Wschodniej. Po II wojnie światowej miasto było jednym z niewielu polskich ośrodków, które zachowało historyczną strukturę zabudowy, jednak utraciło ok. 80\% ludności. W powojennej Łodzi działalność przemysłowa została zahamowana przez wprowadzenie systemu gospodarki centralnie planowanej. Ponadto miasto utraciło podstawowy rynek zbytu po upadku Związku Radzieckiego, tracąc pozycję głównego wytwórcy tkanin na rzecz wyrobów z Chin. Kluczowym momentem dla miasta była transformacja ustrojowa i gospodarcza w Polsce po 1989 roku. Rozpoczął się proces stopniowego upadku potencjału gospodarczego, jakim był przemysł włókienniczy w Łodzi. Doprowadziło to do degradacji obiektów pofabrycznych na szeroką skalę, szczególnie w obszarze śródmieścia i centrum. Skutkiem kryzysu okazało się również wystąpienie znacznej depopulacji w Łodzi, wywołanej ujemnym przyrostem naturalnym oraz wzrostem wyjazdów emigracyjnych (Cudny, 2012).

Najważniejsza historycznie ukształtowana zabudowa przemysłowa z XIX wieku występuje w obrębie Strefy Wielkomiejskiej, będącej najbardziej jednorodną historycznie strukturą centrum miasta (Strategia zintegrowanego rozwoju Łodzi 2020+, 2012). Struktura przestrzenno-funkcjonalna zabudowy podlegała głębokim zmianom, określanym jako proces dezindustrializacji bezwzględnej. Do momentu upadku większości zakładów włókienniczych występowała znaczna redukcja zatrudnienia, wielkości produkcji oraz użytkowania terenu. Większość obiektów pofabrycznych nie jest użytkowana i podlega procesom degradacji, a na terenie nielicznych funkcjonują małe i średnie podmioty gospodarcze sektora usług, zatrudniające przeciętnie kilka osób i użytkujące niewielką powierzchnię (Marczyńska-Witczak, 2001). 
Zaadaptowanie Białej Fabryki Ludwika Geyera na Centralne Muzeum Włókiennictwa w 1956 roku dało początek procesowi przemian terenów poprzemysłowych w Łodzi. Muzeum dysponuje jedną z najokazalszych w Europie kolekcji zbiorów dziedzictwa przemysłu włókienniczego. Pełni także funkcję organizatora Międzynarodowego Triennale Tkaniny - najstarszej i największej na świecie wystawy współczesnej tkaniny artystycznej. Na terenie kompleksu muzeum mieści się Skansen Architektury Drewnianej, prezentujący zabudowę i wnętrza charakterystyczne dla Łodzi w XIX wieku.

Dużym przedsięwzięciem było przeprowadzenie rewitalizacji dwóch największych kompleksów pofabrycznych w Łodzi. Jednym z nich jest 27-hektarowy teren XIX-wiecznego imperium przemysłu włókienniczego fabrykanta Izraela Poznańskiego. Działania naprawcze rozpoczęto w 2006 roku, adaptując zabytkowe obiekty na centrum handlowo-rozrywkowo-kulturalne Manufaktura. Poza pełnieniem funkcji handlowych w obiekcie Manufaktury znajduje się oddział Muzeum Sztuki, Muzeum Historii Miasta Łodzi oraz Muzeum Fabryki. Ważnym elementem rewitalizacji kompleksu było zagospodarowanie 3-hektarowego placu miejskiego, który jest obecnie jedną z ważniejszych przestrzeni publicznych w skali miasta (Dzieciuchowicz, 2012).

Przykład drugiego zrewitalizowanego kompleksu pofabrycznego stanowi Księży Młyn, 5,7-hektarowy teren byłej przędzalni bawełny, należący do łódzkiego fabrykanta, Karola Scheiblera. Obszar nazywano „miastem w mieście” ze względu na występowanie wraz ze strefą przemysłową budynków mieszkalnych dla robotników oraz obiektów usług publicznych. Obecnie w obiektach pofabrycznych znajdują się lokale mieszkalne „U Scheiblera", zwane loftami. Dokonano modernizacji istniejących budynków mieszkalnych oraz wprowadzono nowe funkcje, w szczególności kulturalno-artystyczne i usługowe. W obiektach pofabrycznych powstał Art. Inkubator, czyli instytucja otoczenia biznesu wspierająca osoby kreatywne w działalności rynkowej oraz inicjatywy mające promować kulturę i sztukę (Zintegrowany program rewitalizacji Księżego Młyna, 2012).

Stosunkowo nowatorskim pomysłem stało się utworzenie w obiektach byłych przędzalni i tkalni Franciszka Ramischa miejsca Off Piotrkowska. Jego zasadniczą funkcją jest powstanie atrakcyjnego centrum kulturalnego, skłaniającego do aktywizacji mieszkańców Łodzi. Jest to miejsce przede wszystkim dla ludzi młodych, artystów, projektantów i przedstawicieli przemysłów kreatywnych. Na parterze budynków utworzono przestrzenie do rozwoju inicjatyw z dziedzin szeroko pojmowanej kultury i sztuki. Off Piotrkowska stwarza warunki do funkcjonowania małych i średnich biznesów działalności kreatywnej i jest miejscem alternatywnym dla głównego nurtu komercyjnego (Stopczyńska, 2013).

Spośród analizowanych miast Łódź najpóźniej rozpoczęła proces przemian w obrębie terenów poprzemysłowych. Miasto w swoich sztandarowych działaniach przenosi dobre wzorce wypracowane wcześniej w Manchesterze, adaptując istniejącą zabudowę postindustrialną do nowych funkcji. Niewielka liczba projektów rewitalizacyjnych występujących punktowo w strukturze przestrzennej miasta została zakończona lub nadal jest w trakcie realizacji. Zdecydowana większość terenów pofabrycznych wymaga wdrażania kolejnych procesów naprawczych. Miejsca przemian obecnie pełnią zasadniczą funkcję turystyczną oraz stanowią miejsce spędzania wolnego czasu dla 
Ryc. 3. Najważniejsze inwestycje zagospodarowania obiektów pofabrycznych w procesie rewitalizacji w Strefie Wielkomiejskiej miasta Łodzi

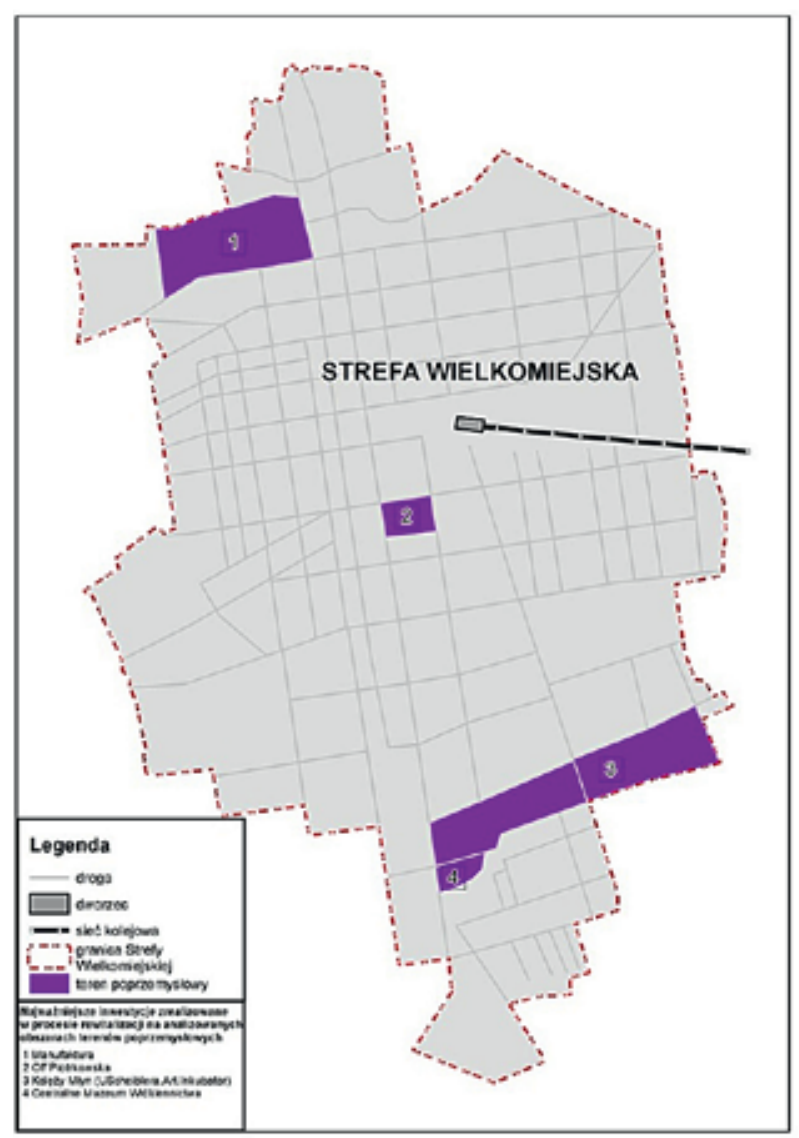

Źródło: opracowanie własne

mieszkańców (Centralne Muzeum Włókiennictwa, centrum handlowe Manufaktura). Stworzono również perspektywy do wzrostu zatrudnienia, zakładania małych przedsiębiorstw i kreatywnych inicjatyw (Art. Inkubator, Off Piotrkowska).

Znaczne rozproszenie oraz mniejsza powierzchnia terenów poprzemysłowych Łodzi w stosunku do tych w Manchesterze i Lyonie utrudnia prowadzenie procesu rewitalizacji jako skoordynowanego i zintegrowanego działania wielkoobszarowego. Miasto rozpoczęło wstępną fazę przekształceń terenów poprzemysłowych, która odbywa się obecnie w sposób punktowy (ok. 36 ha powierzchni wszystkich inwestycji zrealizowanych na terenach poprzemysłowych wskazanych na ryc. 3). Obecnie miasto wprowadza kompleksowe działania w ramach Gminnego programu rewitalizacji dla miasta Łodzi 2020+. Planowana powierzchnia obszaru rewitalizacji wynosi 1331 ha, co stanowi 4,53\% całkowitej powierzchni Łodzi, a zamieszkuje go 119170 osób, co stanowi $17,87 \%$ populacji mieszkańców. 


\section{WNIOSKI}

Analiza porównawcza wybranych trzech ośrodków miejskich ukazała zasadnicze różnice w prowadzeniu działań naprawczych w miejscach dziedzictwa przemysłu włókienniczego. Miasta objęte analizą dysponowały podobnymi uwarunkowaniami geograficznymi, sprzyjającymi rozwojowi przemysłu w ich historii. Jednak moment industrializacji w analizowanych ośrodkach kształtował się niejednakowo. Najpóźniej swoje działania rewitalizacyjne w obrębie kompleksów pofabrycznych wdrażała Łódź. Zasadnicza różnica w modelu prowadzenia działań rewitalizacyjnych występuje w Lyonie i Manchesterze.

Manchester jako miasto o bogatej historii jednostki przemysłowej prowadził działania zmierzające do zachowania tożsamości i dziedzictwa w postaci dużych kompleksów pofabrycznych - była to rewitalizacja właściwa sensu stricte. Podstawowym celem było zachowanie istniejącej zabudowy historycznej, zaadaptowanie jej do nowych funkcji oraz wprowadzenie specjalnej formy ochrony kompleksów. Dotyczy to przede wszystkim przemian przestrzenno-funkcjonalnych w dzielnicy Castlefield, mającej najlepiej zachowaną historyczną zabudowę poprzemysłową. Utworzenie Parku Dziedzictwa Miejskiego dało początek prowadzeniu rewitalizacji w sposób kompleksowy i tym samym wygenerowaniu potencjału turystycznego. Współcześnie jest to jedno z najczęściej odwiedzanych miejsc przez turystów zainteresowanych poprzemysłowym dziedzictwem kulturowym. Miasto, udostępniając nietypową ofertę, znacznie zwiększyło swoją atrakcyjność turystyczną.

W Lyonie - ze względu na historycznie uformowane centrum stanowiące główną atrakcję turystyczną - zrezygnowano z przedsięwzięć wykorzystujących obiekty pofabryczne w celach turystycznych. Zasadnicza większość kompleksu poprzemysłowego znajdującego się w południowej części miasta w dzielnicy Confluence została wyburzona i zastąpiona nową zabudową - była to rewitalizacja sensu largo. Realizowano założenia poszukiwania nowej marki jako miejsca rozwoju kultury i rozrywki. W strategicznych działaniach miasto wyparło historyczną tożsamość dzielnicy przemysłowej. Proces rewitalizacji zakłada modyfikację istniejącej przestrzeni poprzez rozszerzenie miejskiej oferty turystycznej o nowe instytucje i urządzenia.

W porównaniu z Manchesterem i Lyonem Łódź ma najmniejsze doświadczenie w prowadzeniu projektów rewitalizacyjnych.. Znaczna część terenów poprzemysłowych znajduje się w Strefie Wielkomiejskiej. Projekty flagowe dla najważniejszych historycznie obiektów są ukończone lub w trakcie realizacji. Łódź, biorąc przykład z Manchesteru, realizuje wprowadzanie nowych funkcji i ożywianie istniejącej zabudowy. Jednak na razie są to projekty punktowe w przestrzeni miasta, a ich oddziaływanie ma raczej charakter dośrodkowy. Przekształcenie terenów poprzemysłowych w Łodzi pozwoliło również na utworzenie nowych przestrzeni publicznych dla mieszkańców, korespondujących z tożsamością historyczną miejsca. Miasto rozpoczęło kolejne przedsięwzięcia w ramach rewitalizacji i może przenosić przykłady z działań w Manchesterze i Lyonie, wykorzystując je w odpowiedni sposób w celu uzyskania pozytywnych efektów.

Podsumowując przedstawioną analizę, należy podkreślić, że w każdym z ośrodków miejskich rewitalizacja poprzemysłowego obszaru przebiegała w inny sposób. 
Sam proces jest złożony i wymaga nakładów finansowych oraz czasu. Wypracowano dwa modele działania: z zachowaniem istniejących obiektów pofabrycznych i wprowadzeniem nowych funkcji oraz wykreowaniem nowego wizerunku obszaru, tworząc zupełnie nową zabudowę. Ważną kwestią, wymagającą podkreślenia, jest sposób zmiany funkcji terenu, powodujący powstawanie pozytywnych efektów na płaszczyźnie społecznej, ekonomicznej i rekreacyjnej oraz na obszarach sąsiadujących. Przemiany terenów poprzemysłowych powinny wykorzystywać potencjał miejsca oraz łączyć się w zintegrowanym systemie, stymulując kształtowanie przestrzeni miejskiej.

\section{Literatura \\ References}

Carpenter, J. ,Verhage, R. (2014). Lyon City Profile. Cities, 38, 57-68.

Coudroy de Lille, L. (2003). Lyon Confluence - metropolitalny projekt w widłach Rodanu i Saony w Lyonie. W: I. Jażdżewska (red.). Funkcje metropolitalne i ich rola w organizacji przestrzeni. XVI Konwersatorium Wiedzy o Mieście. Łódź: Wydawnictwo Uniwersytetu Łódzkiego, 267-275.

Cudny, W. (2012). Socio-economic changes in Lodz - the results of twenty years of system transformation. Geographical Journal, 64(1), 3-27.

Domański, B. (2001). Przekształcenia terenów poprzemysłowych w województwach śląskim i małopolskim - prawidłowości i uwarunkowania. Prace Komisji Geografii Przemysłu Polskiego Towarzystwa Geograficznego, 3, 52-59.

Dzieciuchowicz, J. (2012). Wielkie centrum handlowe w przestrzeni miejskiej i podmiejskiej. Manufaktura w Łodzi i Ptak w Rzgowie. Łódź: Wydawnictwo Uniwersytetu Łódzkiego.

Gibson, Ch. (1997). The Role of Tourism in Restructuring Region and the Creation of a New Image of the City in Manchester. W: S. Liszewski, C. Young (red.). A Comparative Study of Łódź and Manchester. Geographies of European Cities in Transition. Łódź: Wydawnictwo Uniwersytetu Łódzkiego, 263-277.

Han, J.-H., Kim, Y.-L., Choi, Y.-J. (2014). Characteristics of Spatial Structure and Sustainable Planning in Urban Mixed-use Development Project of Lyon Confluence. Korea Planners Association, 49(4), 121-140.

Kaczmarek, S. (2004). Tereny poprzemysłowe w miastach - problem czy wyzwanie? W: J. Słodczyk (red.). Przemiany struktury przestrzennej miast w sferze funkcjonalnej i społecznej. Opole: Wydawnictwo Uniwersytetu Opolskiego, 155-165.

Kaczmarek, S., Kaczmarek, J. (2010). Tereny poprzemysłowe w Łodzi jako element potencjału miasta. W: T. Markowski, S. Kaczmarek, J. Olenderek (red.). Rewitalizacja terenów poprzemysłowych Łodzi. Biuletyn Komitetu Przestrzennego Zagospodarowania Kraju Polskiej Akademii Nauk, CXXXII, 68-79.

Kazimierczak, J. (2012). Wpływ rewitalizacji terenów poprzemysłowych na kształtowanie nowej miejskiej przestrzeni turystycznej. Przykład Manchesteru i Lyonu. Turyzm, 22(1), 11-21.

Kazimierczak, J. (2014). Wpływ rewitalizacji terenów poprzemysłowych na organizację przestrzeni centralnej w Manchesterze Lyonie i Łodzi. Łódź: Wydawnictwo Uniwersytetu Łódzkiego.

Kidd, A. (1993). Manchester. Manchester: Ryburn Publishing, Keele University Press.

Koter, M. (1994). Od fizjonomii do morfogenezy i morfologii porównawczej. Podstawowe zagadnienia teoretyczne morfologii miast. W: M. Koter, J. Tkocz (red.). Zagadnienia geografii historycznej osadnictwa w Polsce. Materiały konferencyjne. Toruń-Łódź: Uniwersytet Mikołaja Kopernika, Uniwersytet Łódzki, 23-32. 
Liszewski, S. (1997). The Origins and Stages of Development of Industrial Łódź and the Łódź Urban Region. W: S. Liszewski, C. Young (red.). A Comparative Study of Łódź and Manchester. Geographies of European Cities in Transition. Łódź: Wydawnictwo Uniwersytetu Łódzkiego.

Lorens, P., Martyniuk-Pęczek, J. (red.) (2009). Wybrane zagadnienia rewitalizacji miast. Seria Miasto-Metropolia-Region. Gdańsk: Wydawnictwo Urbanista.

Maciejewska, A., Turek, A. (2014). Rewitalizacja obszarów poprzemysłowych ze szczególnym uwzględnieniem uwarunkowań środowiska przyrodniczego - wybrane studia przypadków. Problemy Rozwoju Miast, 2, 81-94.

Marczyńska-Witczak, E. (2001). Procesy dezindustrializacji przestrzennej w latach dziewięćdziesiątych na przykładzie Łodzi. Prace Komisji Geografii Przemysłu Polskiego Towarzystwa Geograficznego, 2, 41-48.

Milestone, K. (2016). 'Northernness', gender and Manchester's creative industries. Journal for Cultural Reaserch, 20(1), 45-59.

Stopczyńska, K. (2013). Wykorzystanie nowych technologii w komunikacji wizerunkowej na przykładzie Off Piotrkowska Center. W: Przedsiębiorczość - droga do innowacyjnej gospodarki. Ekonomiczne Problemy, Usług, 109(795), 217-230.

Straszewicz, L. (1987). Lyon - przemiany wielkiej metropolii regionalnej Europy Zachodniej. Acta Universitatis Lodziensis. Folia Geographica, 8, 131-163.

Strategia zintegrowanego rozwoju Łodzi 2020 + (2012) (2016, 12 stycznia). Pozyskano z http:// www.uml.lodz.pl/miasto/strategia/

Świerczewska-Pietras, K. (2009). Rewitalizacja zamknięta jako przykład zagospodarowania poprzemysłowego obszaru Łodzi. Prace Komisji Geografii Przemysłu Polskiego Towarzystwa Geograficznego, 12, 173-181.

Uchwała nr XLIII/824/12 Rady Miejskiej w Łodzi z dnia 25 czerwca 2012 r. w sprawie przyjęcia Strategii zintegrowanego rozwoju Łodzi 2020+.

Uchwała nr XLV/843/12 Rady Miasta w Łodzi z dnia 4 lipca 2012 r. w sprawie przyjęcia Zintegrowanego programu rewitalizacji Księżego Młyna.

Zintegrowany program rewitalizacji Księżego Młyna (2012) (2016, 12 stycznia). Pozyskano z http://bip.uml.lodz.pl/_plik.php?id=29848

Magdalena Miśkowiec, mgr, Uniwersytet Jagielloński w Krakowie, Wydział Biologii i Nauk o Ziemi, Instytut Geografii i Gospodarki Przestrzennej. Studentka studiów doktoranckich na kierunku geografia na Uniwersytecie Jagiellońskim w Krakowie, pracownik Instytutu Rozwoju Miast w Krakowie. Zainteresowania badawcze to przede wszystkim procesy zachodzące w planowaniu przestrzennym, urbanistyce oraz rewitalizacji miast i obszarów wiejskich. W kręgu zainteresowań są również zagadnienia dotyczące partycypacji społecznej w projektach planistycznych oraz kształtowanie systemów przestrzeni publicznych.

Magdalena Miśkowiec, Jagiellonian University in Cracow, Faculty of Biology and Earth Sciences, Institute of Geography and Spatial Management. I am a Ph.D. student of geography at the Jagiellonian University in Krakow. I am also an employee of the Institute of Urban Development in Cracow. My research interests are mainly processes in spatial planning, urban studies and revitalization of cities and rural areas. Issues related to public participation in planning projects and creating the systems of public spaces are also my field of interest.

\section{Adres/address:}

Uniwersytet Jagielloński

Wydział Biologii i Nauk o Ziemi

Instytut Geografii i Gospodarki Przestrzennej

ul. Gronostajowa 7, 30-387 Kraków, Polska

Instytut Rozwoju Miast

Cieszyńska 2, 30-015 Kraków, Polska

e-mail: magda.miskowiec@doctoral.uj.edu.pl 